\title{
COMMUNITY MANAGEMENT FOR COASTAL ENVIRONMENT IN MANGROVE ECOSYSTEM
}

\author{
Muammar Gomareuzzaman \\ Department of Environmental Engineering, UPN "Veteran" Yogyakarta \\ Jl. SWK 104 Condong Catur, Depok, Sleman, Yogyakarta, mr.gomareuzzaman@gmail.com
}

\begin{abstract}
Mangrove are typical coastal ecosystem, which has high tolerance for salinity, generally located on the coast that has amount of sediments with warm climate. Protect from waves, as well as areas affected by tides and input of freshwater and material from mainland. The objectives of research area; identify natural resources which support mangrove existence; and community participation to conserve.

The research has been conduct qualitative method use deductive approach, which means of field work observation, semi-structure interview, and documentation. The main objects of the research are: (1) coastal plant, i.e. true mangrove; (2) coastal community, which give effort for coastal life and the problems.

The Coastal community has been learning from previous problems that happened continuously on coastal area. They have known how to face with individual and group action plan, such as seeding mangrove plant and regularly togetherness has reforestation program both community and government.
\end{abstract}

Keywords: community, coastal, mangrove ecosystem

\section{INTRODUCTION}

Coastal area covered land area only, boundaries towards seas bounded by shorelines and towards lands bounded by the outer boundaries of coast landforms (Sunarto, 2001). Coastal area has a strategic and important characteristic, combination of marine and land activities. Five characteristics, which according to Nugroho, et al., (2004) should know to manage in accordance with sustainable management, such as: (1) Components of biological and non-biological resources in the coastal area; (2) Component of ecology and location factor; (3) Component of community; (4) Utilization of coastal areas are ecologically and economically; (5) Coastal areas especially towards the sea are generally still a common property resource which can be used by everyone.

Marsono and Setyono (1993) explains that mangrove as coastal ecosystems, which is typical and specific ecosystem, generally located on little choppy of the coast with the warm climate, and protected from waves, as well as areas affected by tidal and the input of freshwater from the mainland. In the mangroves, there are four main factors that determine the spread of mangrove vegetation, such as: (a) The tidal currents frequency; (b) Water salinity; (c) Water temperature; and (d) Ground water.

According to Supriharyono (2000), although mangroves could grow in poor environmental conditions, but each type of mangrove have a limited ability to defend themselves from physicalchemical environment attack. Saenger et al., (1983) explained that there were some influence of physical-chemical environmental conditions of seawater is necessary for the growth of mangroves: (1) Tide level; (2) Salinity; (3) Sea currents; and (4) Temperature. 
Coastal area is location where the landward boundary includes parts of both dry land and groundwater, which is still influenced by the activities of the sea, such as tides, wind and salt water intrusion. While the seaward boundary includes part of the sea that is still influenced by the land natural processes, such as material sedimentation and flow of freshwater, as well as those caused by human activities, such as deforestation, agriculture and pollution.

North Batang coastal area has been the part of Greenbelt Program of North Central Java coastal area, which has program to focusing on coastal plant existence for shoreline change possibility. The existence of coastal plant, especially true mangrove needs to conserve and manage well and controlling from human utilization of mangrove product, such as woods.

In coastal area, such as Batang, mangrove ecosystem has been important land cover vegetation because of the effect of tidal activities by the seas, also sea level rise and shoreline change increase number, easy to intrusion the mainland without barrier. Nowadays need to understanding coastal community needs of materials for living and household without influence and over utilization of coastal plant as coastal barrier.

These research objectives focused on environmental potential that could cover and minimalist

the impact of shoreline change and sea level rises with coastal plants, such as mangrove, also describe the population as relative people or group who has activities and influence environments and vegetations condition surrounding coastal area, especially true mangrove conservation, even the group of people who are not stay and living permanently in there and just doing economic activities.

The main advantage of this mangrove ecosystem research gives appropriate recommendation for Government to formulate regulations to protect coastal area with vegetations (greenbelt) and community advantage from goods maintained of mangrove ecosystem.

Before data collection, field orientation and observations needed to cover the entire region to see the general characteristic and stands composition in the local tidal conditions. To obtain appropriate information with the objectives of the study required information from appropriate sources, and from the people, the right and relevant. Purposive sampling chosen by author according to research primary data needs which collected to answer research objectives related with true mangrove utilizations and community participation.

\section{METHODOLOGY}

This research study conduct in 2 stages: (1) Field orientation and observations, (2) Interviews with key persons to identify community participation. Before data collection, field orientation and observations needed to cover the entire region to see the general characteristic and stands composition in the local tidal conditions. Sampling will be conducted with purposive sampling with 
consideration of the density of true mangrove. To obtain appropriate information with the objectives of the study required information from appropriate sources, and from the people, the right and relevant. Purposive sampling chosen by author according to research primary data needs which collected to answer research objectives related with true mangrove utilizations and community participation.

\section{RESULTS AND DISCUSSION}

\subsection{Description of Batang District}

Batang is district in the northern coast of Central Java Province in Indonesia and the capital is Batang, about $100 \mathrm{~km}$ west of Semarang, Province Capital of Central Java. Batang District covers an area of approximately 78864.16 ha and consists of 15 subdistrict and 239 villages. Batang District has coastal area with a long coastline of approximately $38.75 \mathrm{~km}$ (showed in Figure 1), width of 4 nautical miles so that the broad waters of $287.06 \mathrm{~km}^{2}$, which consists of coastal villages, amounted to 13 villages. Batang District has 4 major rivers, such as: (1) Sambong River, (2) Boyo River, (3) Urang River, and (4) Kuto River, which is included in the Pemali Comal Watershed and divided into several sub-watersheds, which Sengkarang Watershed, and Lampir Watershed. Batang administrative boundaries of the area, north is Java Sea, east is Kendal District, south is Wonosobo District and Banjarnegara Subdistrict, west is the city and district of Pekalongan.

Batang coastal area has a dynamic coastal system, which biodiversity and ecological features. Vegetation of mangrove ecosystem is affected by landuse change and landuse dynamics of the watershed and java seas current and waves. In Batang District, increasing number of sea level rise had already decreasing number of jasmine flower productions because of the high level of salty water in land make the plant dry and land becomes unproductive anymore. Coastal area management should arrange systematically on Strategic Planning which appropriate with coastal community needs and conservation aspect that gives optimal utilization for economic development, community socio-culture, and business opportunity for investor.

Topography of Batang District divided into 2 region, north side that dominant with coastal area and south side as hill to mount area with elevation 100 to $200 \mathrm{~m}$ above sea level. Batang District topography, mostly undulating while the terrain width is relatively small, which is on the west, and east Batang north coast area. Batang coastal area elevated level between 0 to 2,565 m above sea level. Potency of coastal area in Batang District, analyzed based on map orientation of research area and also fieldwork to collect data. North Batang coastal area is an area that has potential natural resources, cause of included on North Java Green Belt.

\subsection{Environmental resources}


Coastal area is location where the landward boundary includes parts of both dry land and groundwater, which is still influenced by the activities of the sea, such as tides, wind and salt water intrusion. While the seaward boundary includes part of the sea that is still influenced by the land natural processes, such as material sedimentation and flow of freshwater, as well as those caused by human activities, such as deforestation, agriculture and pollution.

As meeting point between land and sea, coastal areas has an important strategic meaning, both in terms of ecological, biological diversity, food security, economic, socio-cultural or natural beauty, as well as the prevention of erosion/ abrasion, sea waves and storms. In addition, coastal areas provide economic resources for the activities of trade and industry, mineral resources, energy resources, oil and gas and other mineral materials. The beautiful beach and coral diversity with different types of marine life to supports the development of the tourism industry.

Sediment material supplies as the main factor to support mangrove growth in coastal area mainly deposited along shoreline by long shore current and sourced from 7 major watersheds in Batang District, such as Kuto and Damar watershed. Estuarine ecosystem in the Batang District, located on the river estuary Sambong, Kalikuto, and Kali Urang. Estuarine ecosystem conditions in the Batang District coastal area, during the dry season is not a decline, both water quality and water discharge.

In Sambong river estuary, Kalianyar, and Kaliurang, the process of mixing and eddies (surface and base) is very large. This area is converging with the sediment content is quite high so it needs to be carefully considered in establishing the building of coastal protection, and relatively long bridge worth of the river. High sediment content of the river water in the river estuary Sambong and Kalikuto need attention in the management and utilization, including its role in accelerating the sedimentation. The area surrounding estuarine ecosystem, covered with mangrove vegetation, this is because the material that making up the land dominated by sand material mixed with mud, and clay (sandy clay loam). Total wide area of Batang District mangrove ecosystem could explain from Table 1: 


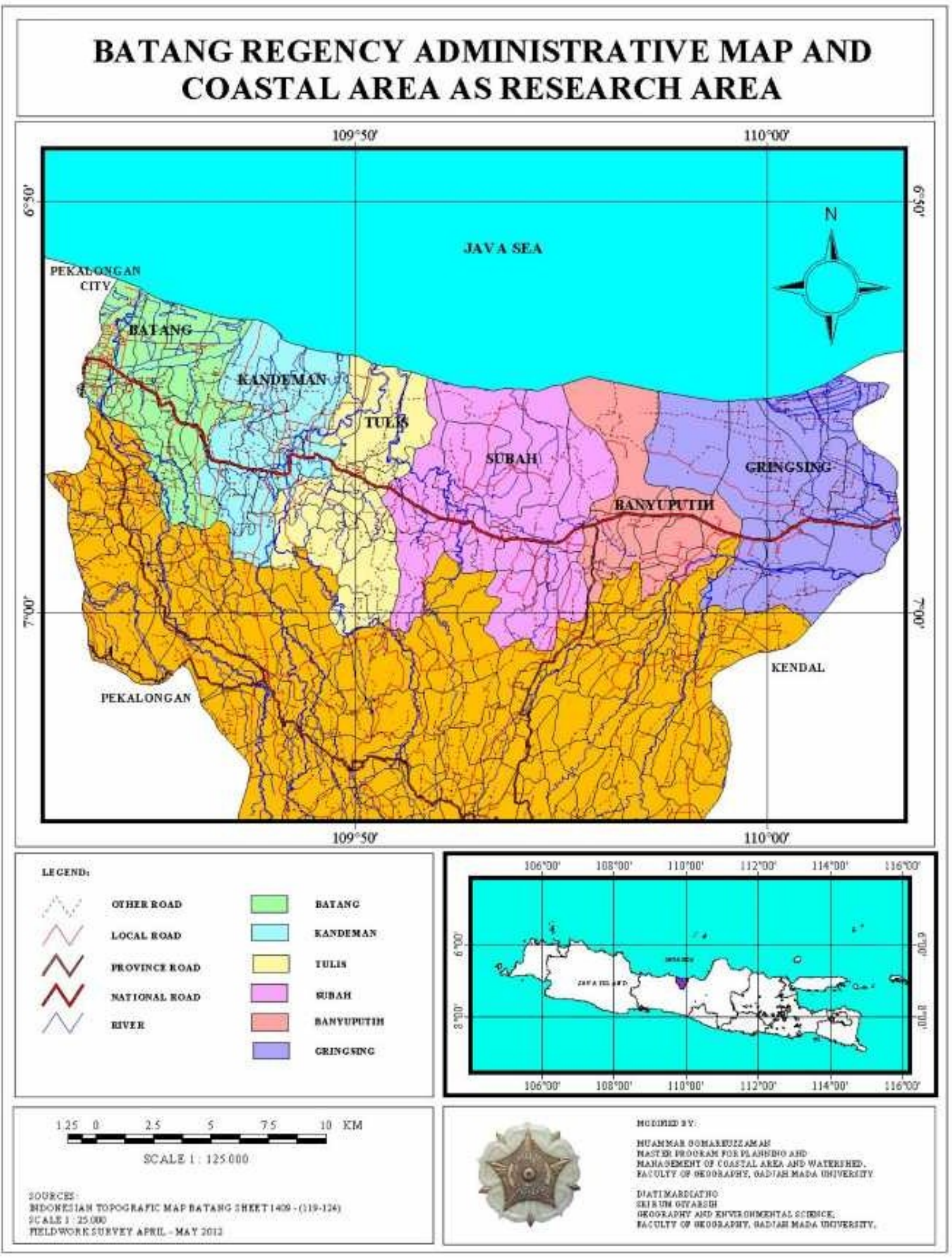

Figure 1 Batang Coastal Area Map 
Table 1 Mangrove ecosystem of Batang District

\begin{tabular}{|l|c|c|c|}
\hline \multicolumn{1}{|c|}{ Villages } & Subdistrict & Aster 2006 (ha) & Landsat 7 ETM+2003 (ha) \\
\hline Denasri Kulon & Batang & 9,6128 & 5,4475 \\
\hline Karangasem Utara & Batang & - & 1,8402 \\
\hline Kasepuhan & Batang & - & 6,4355 \\
\hline Klidanglor & Batang & - & 1,8402 \\
\hline Depok & Kandeman & - & 3,0149 \\
\hline Sengon & Subah & 1,4233 & 3,2133 \\
\hline Kuripan & Subah & 0,3439 & 4,9042 \\
\hline Kedawung & Banyuputih & 1,4456 & 1,3821 \\
\hline Ketanggan & Gringsing & - & 0,9279 \\
\hline Sawangan & Gringsing & - & 1,6916 \\
\hline Sidorejo & Gringsing & 9,9542 & 2,4395 \\
\hline Yosorejo & Gringsing & 6,0305 & 3,2473 \\
\hline Total & & 28,8103 & 36,3842 \\
\hline
\end{tabular}

Source: Analysis of Aster Imagery, 2007by Marine and Fisheries Institution of Batang District, 2011

Species that configured mangrove ecosystems in Batang District classified into 3 components, such as mangrove component of major, minor and associations. Species included in major components that found in the field, such as Rhizophora mucronata, Rhizophora apiculata, Avicennia marina and Bruguiera cylindrica. These species configured most of existing mangrove vegetation in Batang. Minor component of existing species in the mangrove ecosystem found in Batang District only Excoecaria agallocha. While species associations were found, such as waru, ketapang, and marine fir. Waru and ketapang can be found at Kuripan beach, while marine fir is found in Sigandu beach, Depok Village.

According to the Batang Regent decision No.556/ 596/ 2001, established Sigandu Beach in Klidang Lor Village, Batang District, as place for tourism object recreational in Batang District. Also Decree of the regent, regional head level II of Batang, No. 6/ 1999, that set the confirmation of Ujungnegoro coastal areas, Tulis District, regional district level II of Batang, as the tourism area. In the year of 2009 Ujungnegoro Beach established as Regional Marine Conservation Area by Indonesian Government. This establishment according to government in every province In Indonesia to maintains and manages conservation area, coastal area based on ecological viewpoint.

Beside works as fisherman, Batang coastal community also has fish and shrimp ponds, total area of ponds in Batang coastal area totalled 131.40 ha, that consist of fish and shrimp ponds. Coastal community of Batang District also plant flower, especially jasmine in their lands. Jasmine is a commodity that supports society life besides work as fisherman. Farmer also filled sides of ponds area in Batang District with planted sengon trees. Beside of harvest period relatively short, farmer planted sengon as alternative plant because has important functions, especially the roots as nitrogen supplier and makes good soils porosity. The development of ponds area in Batang coastal area supporting fish commodity for local needs, the development of ponds area year by year shown on Table 2: 
Table 2 Development Area of Pond Utilization Year 2007-2009

\begin{tabular}{|l|l|c|c|c|}
\hline \multirow{2}{*}{ No } & \multirow{2}{*}{ District } & Year 2007 & Year 2008 & Year 2009 \\
\cline { 3 - 5 } & & Wide Area (Ha) & Wide Area (Ha) & Wide Area (Ha) \\
\hline 1 & Batang & 68,75 & 68,75 & 68,75 \\
\hline 2 & Kandeman & 30,05 & 80,25 & 80,25 \\
\hline 3 & Tulis & 7,15 & 7,15 & 7,15 \\
\hline 4 & Subah & 22,00 & 22,00 & 22,00 \\
\hline 5 & Gringsing & 114,80 & 114,80 & 114,80 \\
\hline \multicolumn{2}{|l}{ Total } & $\mathbf{2 4 2 , 7 5}$ & $\mathbf{2 9 2 , 9 5}$ & $\mathbf{2 9 2 , 9 5}$ \\
\hline
\end{tabular}

Source: Marine and Fisheries Institution of Batang District, 2011

Batang Subdistrict has farmer groups that exist and manage mangrove seeding in every coastal village, there are no data since when the farmer group were formed. Every farmer groups active and regularly prepare mangrove seedling for coastal reforestation program and supplied product for institutional partner. Each group always works together to prepare and also supply mangrove seedling for owned reforestation also comply each other when other villages lack of seedlings for government or community reforestation program. Community influence to conserve true mangrove by self effort and mangrove planted in several year increasing

Besides planting mangrove, reforestation program also invite people to aware and keep the mangrove grown well, also minimize utilization of woods and other part of mangrove. After mangrove planting activities, reforestation process does yet stop that next process is to keep mangrove that planted grow up and lived normally. For this process, government or community has to decide people from community to keep and take care of mangrove seeding that already planted.

Coastal management plan is the mandate of Law Number 27 of 2007 which must be prepared by the local government (provincial and district/ city). Planning consists of four hierarchical, i.e. strategic plans, zoning plans, management plans, and action plans for the management of coastal areas and small islands. In the 2010 the Government Batang performs the first document preparation plan that documents the strategic plan of coastal areas. With the document is expected to give direction to the cross-sector policy planning through the establishment of goals, objectives, and strategies are broad and targeted implementation of the appropriate indicator.

\section{CONCLUSION AND OUTLOOKS}

Batang District natural resources that support community lives besides come from coastal environmental condition, also comes from social aspect that community doing and effort in that area, such as tourism and fisheries, and conservation action that contribute to sustainable management of environment.

Batang coastal community has effort to conserve true mangrove existence with planting, reforestation, and treatment program that regularly and annually arranged by community or 
government to keep mangroves exist and grow fast. Society awareness to cultivate mangrove is more important and should be supported

Batang District government have to give more attention for specific sector to reach development potential sector of Batang coastal area, such as tourism and fisheries. Also need to cooperation and exchange experiences between community and local government related to coastal area management, which government support community conservation action, such as mangrove seeding action and reforestation program.

\section{REFERENCES}

Bengen D.G., 2001. Ecosystems and Coastal and Marine Natural Resources. Center of Coastal and Marine Resources study IPB, Bogor

Biswas SR, Choudhury JK, Nishat A. 2007. Do invasive plants threaten the Sundarbans mangrove forest of Bangladesh? Forest Ecol Manage 245(1-3):1-9

Indriyanto. 2006. Pengantar Budidaya Hutan. Jakarta: Bumi Aksara.

Marsono, D. and Setyono. 1993. Pendekatan Ekologis. Rehabilitasi Kawasan Mangrove. Studi kasus di Pantai Pemalang. Pemalang: Buletin Instiper.

Prokant B, Reeves P. 2007. From fish and forest to salt and shrimp: The changing nature of coastal development policy

Purnomo, Agus R. 2010. Water Quality Assessment Sengkarang River Water Management Efforts in the Watershed in Batang District. Semarang: Diponegoro University

Rasool, Fayyaz; Tunio, Shahzadi; Hasnain, Syed Ali; Ahmad, Ejaz. 2002. Mangrove Conservation along the Coast of Sonmiani, Balochistan, Pakistan. Pakistan: World Wide Fund for Nature Saenger, P., Hegerl, E., \& Davie, J. 1983. Global status of mangrove ecosystems. Commission on Ecology. Switzerland: World Conservation Union (IUCN).

Snedaker, S.C. 1978. Mangroves: Their Value and Perpetuation. Nature and Resources 14: 6 - 13 Sunarto, 1991. Beach Reforestation. Governmental diffuser, Jakarta

Supriharyono. 2000. Preservation and Management of Natural Resources in Tropical Coastal Areas. Jakarta: PT Gramedia Pustaka Utama.

Tam, Nora FY; Wong, YS. 2002. Conservation and Sustainable exploitation of Mangrove in Hong Kong. Hong Kong: Department of Biology and Chemistry

Tomlinson. 1986. The Botany of Mangrove. New York: Cambridge University Press

Wolanski, E., Mazda, Y. and Ridd, P. 1992. In Tropical Mangrove Ecosystems (eds Robertson, A. I and Alongi, D. M.), Coastal and Estuarine Studies, 41, American Geophysical Union, Washington, pp. 43-62. 